\title{
Maria Sylvia Pinto: dos traços biográficos à sua importância para a canção de câmara brasileira
}

\author{
Marcus Vinícius Medeiros Pereira (UFMS, Campo Grande, MS) \\ marcus.ufms@gmail.com
}

\begin{abstract}
Resumo: 0 presente artigo apresenta traços biográficos da cantora, professora e folclorista Maria Sylvia Pinto. A pesquisa sobre Maria Sylvia Pinto integra dissertação de mestrado defendida pelo autor onde são analisadas canções da compositora Helza Camêu reunidas sobre o nome 0 Livro de Maria Sylvia. Apesar de ser uma "imortal", pois era membro da Academia Brasileira de Música, seu nome e seus feitos em prol da canção brasileira vêm sendo esquecidos com o passar do tempo, uma vez que não há nada sobre ela na Academia, a não ser duas fotografias, um recorte de seu obituário e um pequeno esboço de biografia no site www.abmusica.org.br, na internet. As notas biográficas aqui apresentadas baseiam-se nos relatos das personalidades que estiveram em contato com a cantora, em seu currículo, publicado no seu livro A canção de brasileira - da modinha à canção de câmara (PINTO, 1985), e em uma entrevista concedida por Maria Sylvia ao programa Música e Músicos do Brasil, da Rádio MEC, exibida em 28 de março de 1988 - gentilmente cedida pelos diretores desta rádio.
\end{abstract}

Palavras-chave: Maria Sylvia; canção brasileira; cantores brasileiros; traços biográficos de músicos.

\section{Maria Sylvia Pinto: biographical notes and her importance to Brazilian chamber songs}

Abstract: This paper presents biographical notes of the Brazilian singer, teacher and folklorist Maria Sylvia Pinto and is part of the dissertation defended by the author where five songs composed by Helza Camêu (O livro de Maria Sylvia) were analyzed. Despite being an "immortal" - since she was a member of the Brazilian Academy of Music, her name and her efforts in favor of Brazilian songs have been forgotten over time, since there is no information about her at the Academy, except two photographs, a clipping of her obituary and a short biographical sketch in the site www.abmusica.org.br. The biographical notes presented here are based on reports of persons who were in contact with the singer, on her curriculum, published in the book A canção de brasileira - da modinha à canção de câmara (PINTO, 1985), and on an interview by Maria Sylvia to the program Música e Músicos do Brasil, presented at Radio MEC in March, 28, 1988.

Keywords: Maria Sylvia; Brazilian songs; Brazilian singers; biographical notes on musicians..

\section{1 - Notas introdutórias}

Meu primeiro contato com a canção de câmara brasileira se deu por meio de um projeto criado pelo Grupo Resgate da Canção Brasileira e desenvolvido no curso de graduação em música da Universidade Federal de Minas Gerais. 0 Grupo Resgate da Canção Brasileira, formado por professores da Escola de Música da Universidade Federal de Minas Gerais (EMUFMG) e registrado em diretório do CNPq, tem como objetivo principal divulgar e resgatar a canção brasileira com base em estudos fundamentados (cf. BORÉM e CAVAZZOTI, 2007). Para tal, o grupo criou as seguintes frentes de trabalho:
- Criação das disciplinas Oficina de Performance: Canção Brasileira e Pesquisa em Música: Resgate da Canção Brasileira no curso de graduação da Escola de Música da UFMG;

- Criação do guia virtual Canções Brasileiras, em parceria com o Laboratório de Computação Científica da UFMG;

- Projeto A Canção Brasileira - muito além do "Vai Azulão...", que funcionou de 2003 a 2005;

- Criação do projeto de pesquisa $A$ Canção de Câmara Brasileira para Canto e Piano no Mestrado em Música da UFMG; 
A frente de trabalho da qual tomei parte, A Canção Brasileira - muito além do "Vai Azulão..." (MAVA), foi coordenada pela professora de canto da EMUFMG, Luciana Monteiro de Castro, e contou com quatro bolsistas: dois cantores, um pianista e um violonista. Os bolsistas se apresentavam semanalmente em pontos do Campus da Universidade e em diversas localidades de Belo Horizonte, além de se matricularem nas disciplinas oferecidas pelo grupo. Nestas disciplinas, uma metodologia de análise das canções foi desenvolvida e aplicada para o levantamento e inserção de dados no guia virtual, preparando os alunos bolsistas para atividades de pesquisa a fim de um futuro ingresso em programas de mestrado. De acordo com BORÉM e CAVAZZOTI (2007, p.79), o envolvimento de jovens intérpretes e compositores foi o que motivou o oferecimento das disciplinas e seminários, estimulando o "resgate" não somente de obras do passado, mas do gênero.

Como pianista do projeto, tive a oportunidade de conhecer um vasto repertório de canções, interpretando-o não só com os demais bolsistas, mas também com vários outros alunos das disciplinas. Além disso, as atividades como bolsista me permitiram uma aproximação maior com a metodologia de análise e pesquisa desenvolvida pelos docentes integrantes do Grupo Resgate.

0 crescente entusiasmo e envolvimento com a canção de câmara brasileira, aliado à criação da linha de pesquisa no programa de Pós-Graduação da EMUFMG, resultaram na elaboração de minha dissertação de mestrado, em 2007.

A dissertação deu continuidade ao resgate e divulgação da obra da compositora e musicóloga carioca Helza Camêu (1903 - 1995), iniciado pela professora Luciana Monteiro de Castro Silva Dutra. Em sua dissertação de mestrado, Dutra realiza um estudo analítico de uma canção da compositora - Crepúsculo de Outono, op. 25 n. ${ }^{\circ}$-, além de apresentar uma biografia e uma lista de obras de Helza Camêu. As análises poética e musical da canção foram utilizadas como referência metodológica para minha dissertação.

Segundo DUTRA (2001), Helza Camêu atuou ao longo de boa parte do século $X X$, tendo seu trabalho de etnomusicologia reconhecido no Brasil e no exterior.
Entretanto, sua música permanece praticamente ignorada pelos intérpretes brasileiros da atualidade.

\begin{abstract}
Deve-se observar que boa parte de sua ampla produção musical foi interpretada entre 1940 e 1960.0 atual desconhecimento desta obra mostra-se incoerente, especialmente quando se verifica, no estudo de sua biografia, o elevado grau de credibilidade que Ihe conferiram alguns de seus pares de contemporâneos, como Alberto Nepomuceno (1864 - 1920), João Nunes (1877 - 1951), Heitor Villa-Lobos (1887 - 1959), Oscar Lorenzo Fernandez (1897 - 1948), Mário de Andrade (1893 - 1945) e José Cândido de Andrade Muricy (1895 - 1984), figuras importantes na construção da história brasileira. (DUTRA, 2001, p.1-2)
\end{abstract}

O livro de Maria Sylvia foi escolhido como objeto de estudo de minha dissertação de mestrado - intitulada " 0 Livro de Maria Sylvia, Op. 28, para canto e piano, de Helza Camêu (1903 - 1995): Uma análise interpretativa" por revelar traços marcantes da compositora na escrita para canto e piano e por suscitar a memória da cantora Maria Sylvia Pinto, grande batalhadora da Música Brasileira, intérprete das canções e amiga de Helza Camêu.

\section{2 - O Livro de Maria Sylvia}

0 opus 28 da compositora carioca Helza Camêu, intitulado 0 livro de Maria Sylvia, foi composto no Rio de Janeiro entre dezembro de 1944 e janeiro de 1945. Ao final de cada canção, no manuscrito autógrafo, a compositora registra as datas e o local de composição à exceção da última, Canção Triste.

\section{Integram O Livro de Maria Sylvia as canções apresentadas} no Ex.1 abaixo.

Como indica o título do opus, as canções foram, todas, dedicadas a Maria Sylvia Pinto, o que é confirmado pela dedicatória da compositora em cada uma das partituras das canções. Esta foi a única ligação observada entre 0 título do ciclo e as canções.

Os poemas que foram escolhidos para serem musicados e constituírem 0 Livro de Maria Sylvia foram extraídos de três obras diferentes, sendo uma destas de autoria de Manuel Bandeira (Imagem é um poema publicado no livro A cinza das horas, de 1917) e os outros de Olegário Marianno (Espera Inútil é um poema publicado no livro 0 enamorado da vida, de 1937, e A toada da chuva, Canção e Canção Triste são poemas publicados no livro Quando vem baixando o crepúsculo, de 1944). Mesmo os poemas

\begin{tabular}{|c|c|}
\hline CANÇÃo & POETA \\
\hline Imagem & Manuel Bandeira \\
\hline Espera Inútil & Olegário Mariano \\
\hline A toada da chuva & Olegário Mariano \\
\hline Canção & Olegário Mariano \\
\hline Canção Triste & Olegário Mariano \\
\hline
\end{tabular}

Ex.1 - O Livro de Maria Sylvia 
que foram retirados do mesmo livro não estão na ordem em que aparecem publicados.

Tais fatos fortalecem a hipótese de que a compositora estava intencionada a criar uma linha narrativa para as canções. Este fio narrativo foi apresentado ao final da análise dos poemas e canções em minha dissertação:

\begin{abstract}
Em Imagem, nós temos a descrição do eu-lírico que vai cantar todo o livro de canções: um lírio franzino, ansioso, frágil e dolorido. Neste poema nos é narrado o nascimento de uma inconsolável mágoa que torna a vida deste eu-lírico amarga: um amor fadado ao fracasso. Também em Imagem nos é apresentada a sina do eu-lírico: amar e viver incompreendido, ou seja, ter um amor não correspondido.
\end{abstract}

Em Espera Inútil, o eu-lírico marca um encontro com este amor: é um momento de grande excitação. Entretanto, toda a noite passa e, quando chega a madrugada, a espera havia sido em vão: 0 amado não compareceu ao encontro e o eu-lírico chora de decepção, mas finge que suas lágrimas são o orvalho da madrugada.

Em A toada da chuva o eu-lírico se sente só. 0 mundo está como seu interior: pardacento, chuvoso. Há apenas uma andorinha solitária voando neste universo pardacento. Apenas o amor de uma pessoa pode mudar a vida do eu-lírico tornando-a realmente boa e feliz. Entretanto o ser amado parece não correspondê-lo. Desta forma, não há outra andorinha para se fazer verão e não há vida boa para ele.

Em Canção, o eu-lírico tem perto de si a montanha, o céu, o mar, o horizonte, o veio d'água; e tudo o oprime, o sufoca.. Tudo está ao alcance das mãos, menos o ser amado, que não corresponde ao seu amor e se mantém afastado.

Em Canção Triste, notamos que a sina descrita em Imagem se cumpre: o eu-lírico que vem cantando as outras canções, aqui um passante vulgar, passa pela vida sem ter seu amor, sem ter sequer sua sombra. Há nele um grande cansaço da vida, e a esperança de um amor que não aconteceu anoitece definitivamente em seu olhar. Há nesta canção um narrador, que observa e descreve a cena: o passante (eu-lírico das outras canções do ciclo) somese ao longe a chorar, deixando a rua envolta de saudades, tendo realmente vivido e amado, incompreendido. E a lua, embora triste com toda a cena, continua devagar sua trajetória pelos céus.

Separadamente as canções têm seus significados independentes. Entretanto, quando vistas juntas, quando interpretadas juntas, integram um significado maior. A temática que costura todas estas canções é a tristeza, a solidão, a dor de amor. (PEREIRA, 2007, p.126 - 127)

Outra hipótese possivel é a de Maria Sylvia ter escolhido estes poemas para que Helza Camêu musicasse, fato que era comum de acordo com D. Julieta Correa, filha da compositora'.

Infelizmente não foi possivel confirmar a legitimidade de nenhuma destas hipóteses. Entretanto, a figura de Maria Sylvia se destacou como uma personagem importante tanto na vida quanto na obra de Helza Camêu.

Membro da Academia Brasileira de Música, Maria Sylvia Pinto é lembrada pelos que conviveram com ela como um grande nome da música brasileira, tanto como intérprete quanto como pesquisadora.Apesar disso, pouca informação sobre ela foi encontrada na literatura, o que é, em última análise, uma injustiça à sua memória. Buscando corrigir este erro, apresento aqui traços biográficos desta cantora-folclorista tão apreciada por importantes compositores brasileiros de canções - fato comprovado pelo número de canções dedicadas a ela.

Maria Sylvia Pinto, soprano, foi grande divulgadora e pesquisadora da canção e do folclore nacionais. Sua importância se confirma pelo fato de ela ter feito primeiras audições de várias e importantes canções do repertório nacional ${ }^{2}$ e estrangeiro ${ }^{3}$, muitas vezes acompanhada pelos próprios compositores, que a ela dedicaram várias peças. Dedicou um livro à canção brasileira ( $A$ canção brasileira - da modinha à canção de câmara de 1985), que, ao lado do de Vasco Mariz, figura entre os únicos a tratar especialmente do percurso histórico do gênero.

Apesar de ser uma "imortal", pois era membro da Academia Brasileira de Música, seu nome e seus feitos em prol da canção brasileira vêm sendo esquecidos com o passar do tempo, uma vez que não há nada sobre ela na Academia, a não ser duas fotografias, um recorte de seu obituário e um pequeno esboço de biografia no site www. abmusica.org.br, na internet.

As notas biográficas aqui apresentadas baseiam-se nos relatos das personalidades que estiveram em contato com a cantora, em seu currículo, publicado no livro A canção de brasileira - da modinha à canção de câmara (PINTO, 1985), e em uma entrevista concedida por Maria Sylvia ao programa Música e Músicos do Brasil, da Rádio MEC, exibida em 28 de março de 1988 - gentilmente cedida pelos diretores desta rádio.

\section{3 - Maria Sylvia Pinto: traços biográficos}

Maria Sylvia Pinto nasceu na cidade de Sapucaia, Estado do Rio de Janeiro, no ano de 1913, tendo se mudado logo em seguida para a capital. Iniciou seus estudos musicais aos oito anos, já no Rio de Janeiro. Como toda moça da época, iniciou-se cedo no piano, revelando muito talento e um crescente gosto pela música.

Foi aluna de piano de Henrique Oswald, que a incentivou e a preparou para ingressar no Instituto Nacional de Música (INM), hoje Escola de Música da UFRJ. Maria Sylvia ingressou no INM em abril de 1931, na classe de Henrique Oswald. Com a morte de Oswald, em junho do mesmo ano, sua turma passou para as mãos de outro grande músico: Luciano Gallet. Contudo, Luciano Gallet falece prematuramente em outubro de 1931, passando a turma para o professor J. Otaviano. Para ela, J. Otaviano foi um grande professor, um mestre muito exigente. No final de 1931, concluiu o curso, sendo posteriormente preparada por Otaviano para o concurso à Medalha de Ouro em piano do Instituto, prêmio este que ganhou por unanimidade. Depois do concurso à Medalha de Ouro, Maria Sylvia Pinto aperfeiçoou seus estudos de piano em Paris com os professores Isidor Philipp e Alfred Cortot. 
0 canto surgiu na vida de Maria Sylvia por sugestão de uma tia, pela qual ela foi criada. Maria foi aluna de Murilo de Carvalho, maior professor de canto da época, e justificava sua dedicação à interpretação da música de câmara pelo fato de possuir uma "voz pequena".

Seu primeiro concerto foi na Rádio Mayrink Veiga, onde cantou canções francesas. Sua carreira profissional começou, então, na rádio. Posteriormente deu seu primeiro concerto no Instituto Nacional de Música, todo ele voltado à música brasileira. Cantou de modinhas imperiais do século XVIII até as modinhas harmonizadas por VillaLobos, Luciano Gallet, Ernani Braga, entre outros. Maria Sylvia declarou ter sido a primeira cantora a dedicar um concerto inteiro a canções brasileiras, concerto este que gerou certo furor numa época em que cantar em português era considerado de mau-gosto. Seu segundo concerto foi dedicado a canções folclóricas internacionais.

Realizou diversos cursos ao longo de sua vida, dentre eles o Curso Profissional de Canto, Curso de Dicção e Impostação, de Acústica e Biologia aplicadas à Música, Canto Coral, Folclore, Especialização em Folclore (Folguedos Populares) - todos na Escola de Música da UFRJ. Estudou também no Instituto de Estudos Superiores em Montevidéu, no Uruguai. Estudou Impostação de Voz e Oratória e Mitologia Iorubana na Secretaria de Educação do Estado da Guanabara; Dicção e Impostação de Voz na Associação Brasileira de Imprensa, Cerimônias Religiosas de Influência Africana no Museu Nacional do Folclore e Piano no Conservatório Brasileiro de Música.

Foi uma grande pesquisadora do Folclore, tanto o Nacional como o Internacional. Realizava recitais apenas de canções folclóricas e incentivava compositores a harmonizarem temas folclóricos. De acordo com D. Julieta Correa, um grande número das harmonizações folclóricas de Helza Camêu foi feito por sugestão de Maria Sylvia, que achava as composições de Camêu sempre muito tristes.

Maria Sylvia, considerada por muitos como uma grande intérprete, levou a canção por todos os cantos do Brasil: apresentou-se em Recife, Brasília, Goiânia, Rio de Janeiro, São Paulo, Belo Horizonte, Salvador, Curitiba, Petrópolis, Ponta Grossa, Campos, Itajubá, Niterói, Nova Friburgo e Londrina. No exterior, apresentou-se com sucesso em Lisboa, Paris, Montevidéu e Buenos Aires.

0 maior momento de sua carreira se deu por volta de 1962, quando, a convite do Maestro Souza Lima, cantou frente à Orquestra do Estado de São Paulo. Amedrontada de início por causa de sua "pequena voz", ela aceitou o convite (um verdadeiro desafio para ela) para cantar a difícil ária da Sheherazade, de Maurice Ravel. Entretanto, uma semana antes da apresentação, Souza Lima muda de idéia e pede quatro peças avulsas ${ }^{4}$. Logo em seguida, a 16 de junho de 1962, apresentou-se no Teatro de Cultura Artística de São Paulo, acompanhada pelo grande pianista Fritz Jank.
Maria Sylvia desenvolveu, ao longo de sua vida, intensa atividade pedagógica. Começou a lecionar no Conservatório Nacional de Canto Orfeônico, ainda no tempo de Villa-Lobos, ocupando as cadeiras de Fisiologia da Voz e Técnica Vocal. Posteriormente sucedeu Brasílio Itiberê na cadeira de Folclore.

O Conservatório Nacional de Canto Orfeônico mudou de nome, passando a Instituto Villa-Lobos, atual Universidade do Rio de Janeiro (UNIRIO), onde ela lecionou Canto, Folclore, Prosódia Musical (na cadeira que foi de Ademar Nóbrega) e Música de Câmara.

Em um artigo sobre a história do Instituto Villa-Lobos intitulado "O Instituto Villa-Lobos e a Música Popular", Ricardo Ventura narra algumas de suas lembranças enquanto aluno de Maria Sylvia na instituição:

No caso da Técnica Vocal, por exemplo, a professora Maria Sylvia Pinto suportava com grande elegância o enxame de cantores populares que invadia suas aulas, mas não conseguiu admitir, jamais, a "prosódia desengonçada" das letras das canções populares que assombravam suas aulas, principalmente aquele canto "fanho" da Bossa-Nova, muito menos o "rouco" do Rock. Diga-se de passagem, que a profa Maria Sylvia, além de excepcional artista tinha uma habilidade didática primorosa. Foi muito amiga de Villa-Lobos. Pena não se encontrar mais entre nós para contar as histórias super engraçadas que sabia sobre 0 Maestro. (VENTURA, 2005, s.p.)

Lecionou Folclore no Conservatório de Música de Niterói, e ministrou vários cursos de folclore e música brasileira no Brasil e exterior: "Introdução ao Folclore Brasileiro" e "O Brasil através do Folclore", no Instituto Villa-Lobos (Federação das Escolas Federais Isoladas do Estado do Rio de Janeiro - FEFIERJ); "Raizes Folclóricas da Música Popular", no Museu do Folclore (Rio de Janeiro - RJ); "Curso sobre Música Brasileira", no Centro de Estudos Brasileiros de Buenos Aires, Argentina; "O Brasil e seu folclore", na Escola de Música Santa Cecília de Niterói RJ; além de uma "Conferência sobre Música Popular" na Escola de Enfermagem da UERJ.

Maria Sylvia Pinto ocupou a cadeira número 39 - Luciano Gallet - da Academia Brasileira de Música (para a qual havia sido inicialmente eleita no quadro especial de Membros Intérpretes), sucedendo Rossini Tavares de Lima. Grande ativista da Música Brasileira, a cantora realizou inúmeras gravações, das quais se pode destacar a gravação das "14 Serestas" de Villa-Lobos, para a Rádio MEC; além de várias gravações disponíveis no acervo da Rádio MEC, para o programa "Música e Músicos do Brasil" com obras de Nepomuceno, Francisco Braga, J. Otaviano, Francisco Mignone, Helza Camêu e Souza Lima. Gravou também uma série de discos com Modinhas Imperiais para o Museu Imperial de Petrópolis (Departamento de Cultura do Estado da Guanabara); e um programa de "Música Brasileira" para a Rádio Nacional de Buenos Aires - Argentina e para a Rádio SODRE de Montevidéu - Uruguai.

Maria Sylvia faleceu em 1999, no Rio de Janeiro, aos 85 anos de idade. 
Abaixo, uma foto da cantora encontrada no acervo da Biblioteca Nacional - Divisão de Música e Acervo Sonoro (Ex.2):

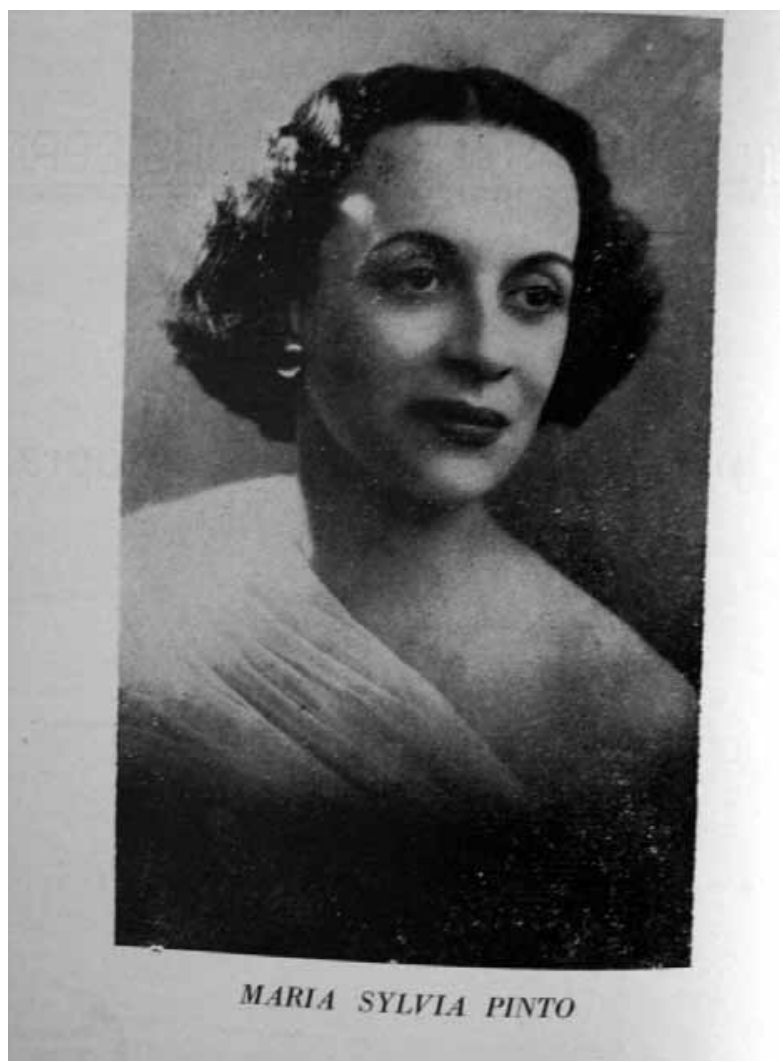

Ex.2 - Foto de Maria Sylvia no programa de recital de 19 de fevereiro de 1950, no Teatro Francisco Nunes, Belo Horizonte (Acervo da Biblioteca Nacional).

\section{4 - Maria Sylvia Pinto - "uma intérprete"}

Maria Sylvia foi muito conhecida em sua época como uma grande intérprete. A própria cantora diz, em entrevista a Lauro Gomes, no programa Música e Músicos do Brasil, exibido em 28 de março de 1988:

\footnotetext{
Realmente, eu tinha uma voz pequena, e como a minha voz era pequena, eu, graças a Deus, tive inteligência suficiente para ver - não estou me gabando - para compreender que eu teria que fazer música de câmara, nada mais ali. Então eu me dediquei à interpretação. Eu me considero uma intérprete. (PINTO, 1988)
}

Várias são as referências às suas qualidades como intérprete. Todos destacam o fato de ela vencer a limitação de possuir uma "voz pequena", usando-a com perfeição:

Ao longo de sua carreira (...) ela se fez respeitar e admirar como musicista de grandes recursos, capaz de estar à vontade em obras dos mais diversos estilos e épocas. (...) Sua sólida formação musical contribuiu em muito para que, durante os estudos de canto com o mestre Murilo de Carvalho, fosse sendo plasmada uma linha de canto que seria uma das caracteristicas de Maria Sylvia. Na falta do vozeirão natural, ela precisou aprimorar qualidades interpretativas que a armassem para a carreira a ser desenvolvida. (NEVES, 1985, p.9)

A cantora lírica Maria Sylvia Pinto compensava a voz pequena com impressionante clareza de dicção, o que lhe permitiu passar com facilidade do clássico para o folclore e o popular. (0 GLOBO, 01/09/1999)
Andrade Muricy, amigo e crítico musical, afirma que "um recital de Maria Sylvia é sempre uma festa de inteligência. É uma intérprete. Leva até o sofrimento a sua expressividade." (JORNAL DO COMÉRCIO apud PINTO, 1985, p.9-10)

Sua interpretação sempre foi muito elogiada pela inteligência musical e dicção perfeita:

A inteligência musical de Maria Sylvia incluia a indispensável lucidez com relação a seus limites vocais, conduzindo-a a descobrir sempre sua maneira própria de conceber e exteriorizar as obras que cantou. Se Deus não lhe deu a grande voz, compensou-a, e muito, com esta brilhante visão da solução musical a ser dada a cada peça de seu enorme repertório. Dentre estas soluções, uma foi constante e sempre eficaz: Maria Sylvia soube dizer o que cantava, e isto era um de seus segredos. Abordando uma simples canção folclórica ou uma obra francesa sofisticada, ela sempre passava a integralidade do texto e sua essencialidade expressiva. Ela se fazia entender em qualquer lingua usada (e ela nem sabe em quantas línguas cantou...), captava o que havia de melhor na musicalidade do som de cada lingua. A crítica mais freqüente aos cantores (em que língua está cantando?) nunca poderia ser aplicada à Maria Sylvia. E esta exigência preliminar, tantas vezes negligenciada pelos cantores, foi sempre o ponto de partida para o trabalho mais profundo de exteriorização musical das obras. Pois se dizer o texto é a primeira exigência do cantor popular ou erudito, o canto nunca foi declamação pura e simples, e o desafio maior colocado face ao cantor talvez seja usar todos os seus recursos de que dispõem para que o dizer se harmonize com os demais elementos do fazer musical. Maria Sylvia soube encontrar esta harmonia. (NEVES, 1985, p.11-12)

Outra faceta desta cantora também foi bastante reconhecida: sua habilidade como camerista e colaboradora de cantores. "Colaboradora" é o termo que Maria gostava de usar no lugar de acompanhadora:

Não nos agrada a palavra 'acompanhamento' quando se trata de tocar uma canção de câmara; o piano não acompanha o canto como o faria em uma modinha. 0 instrumento se entrelaça, se junta, se confunde com a melodia cantada, não se podendo separar do canto a parte pianistica. (...) Assim, é feliz o cantor que (...) conta com um bom pianista, ou melhor, um excelente pianista para colaborar com ele. A palavra acompanhador deveria desaparecer e em seu lugar viria colaborador; infelizmente não se dá a devida importância ao pianista que é, além de executante, um grande auxiliar do cantor. (JORNAL DO COMÉRCIO apud PINTO, 1985, p.9-10)

Sua idéia de "colaborador" vem certamente da experiência como pianista, tendo se apresentado com inúmeros cantores e instrumentistas em atividades camerísticas. Citado por José Maria Neves no Prefácio do livro "A canção brasileira - da modinha à canção de câmara" de Maria Sylvia, Andrade Muricy afirma que ela era uma "pianista e cantora, [que] acompanha e é acompanhada com a mesma eficiência. (...) Maria Sylvia colabora, não acompanha somente, atua de maneira extremamente vivaz e artística" (PINTO, 1985, p.10)

Atuou como pianista-colaboradora dos maiores artistas brasileiros de seu tempo, como Maria Lúcia Godoy, Fátima Alegria, Lia Salgado, Amim Feres, Hermelindo Castelo-Branco, Florita Tolipan, Lauricy Prochet, Nilze Araújo Vianna, Geza Kiszely, Carlos Rato e Alfredo Melo. 
Reafirmando suas qualidades como intérprete, Helza Camêu diz que Maria Sylvia é "uma eterna namorada do canto simples que vem diretamente da alma popular" e acrescenta que ela é "uma artista completa, que conhece profundamente o clima próprio a cada gênero e a cada época". Ainda para Helza Camêu, "o compositor brasileiro tem nela a intérprete ideal" e Maria Sylvia é "uma das maiores, senão a maior intérprete da música brasileira"5.

\section{5 - Maria Sylvia Pinto - "uma ativista da música brasileira"}

Outra característica marcante de Maria Sylvia foi sua atividade como divulgadora e pesquisadora da canção brasileira. Sempre pesquisou o folclore nacional e o divulgou em seus recitais pelo país, alem de incentivar os compositores brasileiros a harmonizarem temas folclóricos. Segundo Muricy, novamente citado por Neves no Prefácio do livro escrito por Maria Sylvia:

\begin{abstract}
...a carreira artística de Maria Sylvia tem sido eminentemente cultural. Por mais longe que leve minhas lembranças a seu respeito, encontro-a divulgando música de exceção, pesquisando, acrescentando ao seu repertório, em que há raridades, novas criações de grande classe ou simplesmente curiosas, e obrasdocumento, representativas da inventiva e da sensibilidade popular. (MURICY apud NEVES, 1985, p.10)
\end{abstract}

Consta no seu obituário, publicado em setembro de 1999 no Jornal 0 Globo, que "Maria Sylvia fez muito sucesso nos anos 50, quando foi uma das maiores divulgadoras da música clássica brasileira, em especial da música de câmara".

Em depoimento por e-mail, o compositor Ricardo Tacuchian diz:

Maria Sylvia era uma verdadeira ativista da Música Brasileira. Ocupava a Cadeira no 39 (Luciano Gallet) da Academia Brasileira de Música. Em função disso (e do fato de sermos colegas na UNIRIO) tínhamos bons contatos. Uma vez a visitei no Flamengo, e ela me mostrou uma impressionante coleção de obras brasileiras para canto, muitas em manuscrito, e outras dedicadas a ela, além de edições raras. Não sei onde foi parar esta preciosidade. Um de seus maiores legados foi o seu livro "A Canção Brasileira" (da Modinha à Canção de Câmara), Rio de Janeiro: Edição do autor, 1985. Que eu saiba, desta natureza só existe o livro do Vasco Mariz. 0 livro é dedicado a Helza Camêu e a Andrade de Muricy, ambos membros da ABM. Guardo saudades da grande mestra com quem não tive 0 privilégio de estudar. (TACUCHIAN, 2007)

0 livro citado por Tacuchian foi publicado em 1985 e é fruto das pesquisas e da experiência de Maria Sylvia Pinto no terreno da música brasileira. As últimas notícias que tivemos desta "impressionante coleção de obras brasileiras" foi de que todo o seu acervo foi vendido em um sebo especializado em partituras da cidade do Rio de Janeiro. 0 dono da loja não quis se pronunciar a respeito da origem do acervo particular de Maria Sylvia; o fato é que, quando soubemos da venda, havia apenas um exemplar disponivel de uma melodia folclórica russa, cópia manuscrita da própria Maria Sylvia. 0 que nos faz suspeitar de que todo seu acervo foi vendido nesta loja é que todas as partituras (e era realmente um número bastante significativo de peças) estavam assinadas pela cantora.
Como já dito anteriormente, ela dedicava-se ao estudo do folclore brasileiro: tratava o folclore como ciência, como parte da antropologia. Considerava-o como uma matéria muito séria a ser estudada. De acordo com José Maria Neves (1985), na interpretação de canções folclóricas ela soube perceber o que dizia Mário de Andrade: quando uma obra muda de local e de função, quase tudo muda. De acordo com Neves, o harmonizador e o adaptador, assim como o intérprete, devem estar muito conscientes disso. Assim, diz ele, muitos cantores julgaram oportuno e necessário colocar trejeitos folclorizantes ou sentiam necessidade de imitar comportamentos e maneiras de artistas do povo ao interpretar canções folclóricas. Ai também Maria Sylvia levou vantagem sobre muitos outros cantores. José Maria Neves conta que ela se fez estudiosa do folclore brasileiro, desenvolvendo interessantes pesquisas sobre algumas de suas manifestações, e transpôs o conhecimento teórico armazenado, bebido direto da fonte, para a nova realidade dentro da qual as peças passavam a viver:

0 resultado foi, justamente, sua maneira tão pessoal de cantar este tipo de música. A dignidade estava sempre presente, a canção era tratada com o respeito que qualquer obra de arte merece, mas sua interpretação e sua exteriorização iam incorporando, sem afetação, os elementos essenciais da expressividade popular. (NEVES, 1985, p.13)

Outro fato que sublinha a sua importância como intérprete e também como ativista da música brasileira foi o seu contato e o reconhecimento conferido a ela pelos maiores compositores brasileiros. Por sua dedicação à música brasileira, foi convidada por Villa-Lobos para integrar a Academia Brasileira de Música, inicialmente na classe especial de membros intérpretes. Sobre o seu relacionamento com os compositores, José Maria Neves relata:

Repertório amplo e variado, e programas sempre marcados por obras não executadas por outros cantores. Quando for feito um estudo aprofundado sobre o repertório vocal brasileiro, a própria cantora se surpreenderá: talvez seja ela a responsável pela maior quantidade de primeiras audições de canções de autores brasileiros, que a ela dedicaram inúmeras obras. $\mathrm{E}$ a fidelidade das interpretações estava garantida pela preocupação da cantora em mostrar, sempre, aos compositores como percebia as obras. De fato, Maria Sylvia teve oportunidade de trabalhar com os compositores as sutilezas de interpretação das obras que colocava em estudo (e seu interesse por obras de compositores vivos derivava, em parte, desta preocupação), assim como buscou os conselhos de mestres estrangeiros para encontrar as melhores soluções interpretativas a serem dadas, por exemplo, às canções de autores franceses ou argentinos que divulgou no Brasil. (NEVES, 1985, p.11)

Maria Sylvia diz, ao final de seu livro:

No nosso ponto de vista, o intérprete cantor não é o dono da verdade em relação à canção que vai interpretar. (...) Infelizmente os compositores mais cantados estão mortos, mas quando há os vivos, eles devem ser consultados e opinar sobre o intérprete. (...) nada melhor do que ouvir do próprio compositor uma opinião sobre o que ele pensa, sobre o que imaginou quando escreveu aquela canção. Nós, sempre que pudemos, recorriamos aos autores para conhecer o seu ponto de vista sobre nossa maneira de cantar. Assim foi com Villa-Lobos, com J. Otaviano, de quem fomos aluna, de F. Mignone; deste então tivemos a ventura de 
cantar inúmeras obras suas e ele sempre tinha alguma coisa a acrescentar. Com Helza Camêu, de quem cantei quase toda a sua obra vocal; com Souza Lima, em S. Paulo, com Waldemar Henrique e Osvaldo de Souza nas canções folclóricas e com Arnaldo Rebelo e Babi de Oliveira. Na argentina ouvimos a crítica de Alberto Ginastera, de Carlos Guastavino e Angel Lasala, este, excelente músico argentino. Em Paris fomos visitar Joseph Canteloube ouvir sua opinião sobre as canções folclóricas francesas por ele harmonizadas. (PINTO, 1985, p.105-106).

Sobre sua relação com Helza Camêu, Maria Sylvia diz que ela é um caso à parte em sua carreira porque houve grande entrosamento entre elas e porque considerava Helza Camêu a maior compositora brasileira. Lamentava o fato de a obra dela não fosse mais conhecida, talvez pelo fato de Camêu ter sido muito reservada. Para ela, Helza não era uma pessoa que se promovia como compositora, sendo muito intimista.

Para finalizar estes traços biográficos de Maria Sylvia Pinto, apresentamos uma foto (Ex.3) que ilustra a parceria de Maria Sylvia com os compositores - neste caso apresentando-se ao lado de Francisco Mignone; e transcrevemos um texto escrito por Helza Camêu, publicado na contracapa do livro escrito por Maria Sylvia sobre a canção brasileira, por vezes aqui citado:

Maria Sylvia Pinto, pianista laureada e cantora renomada, brindanos com uma obra inteiramente dedicada à Arte do Canto, a que, na verdade, proporcionou-lhe toda uma grande e vitoriosa carreira. Abordando a Canção, sobretudo a brasileira, com minúcias de técnica e sensibilidade, a obra em apreço representa uma continuação da sua vivência como musicista, cantora, concertista e professora. Sob qualquer destes ângulos vêmo-la ministrando lições preciosas por refletirem longa experiência, acurado estudo analítico sobre o gênero - do popular ao camerístico. Um trabalho de leitura amena, instrutivo, até para leigos, endereçado principalmente aos jovens aspirantes a cantor e isto, devemos enfatizar, oferecido por uma artista que sempre soube encontrar a cor exata, a inflexão precisa para uma palavra, uma frase musical, um efeito exigido, em suma a interpretação adequada e perfeita, que muitas vezes surpreendeu e lisonjeou o próprio compositor pela colaboração oportuna e precisa. Helza Camêu. Rio, 15/03/1985.

\section{6 - Notas finais}

Os traços biográficos desta personalidade ímpar que foi Maria Sylvia Pinto permitiram conhecer um pouco mais da luta pela canção nacional no Brasil, como também enxergar o descaso com que as personalidades brasileiras são tratadas. A preservação do patrimônio histórico e cultural de um país não se faz apenas com a preservação de bens materiais, como imóveis históricos, roupas e acessórios de época; mas principalmente com a preservação da sua história e memória. É absolutamente lamentável o descaso com que é tratada a memória de uma mulher que dedicou sua vida à pesquisa do folclore nacional e à canção de câmara. A pesquisa sobre a vida de Maria Sylvia e suas atividades no campo da canção de câmara nos fez questionar sobre qual seria o significado de se tornar membro da Academia Brasileira de Música e assim ser um imortal. E permitiu também perceber que o trabalho em prol do resgate e da divulgação da canção nacional já vem sendo traçado com grande empenho e competência há algum tempo, dando-nos força para

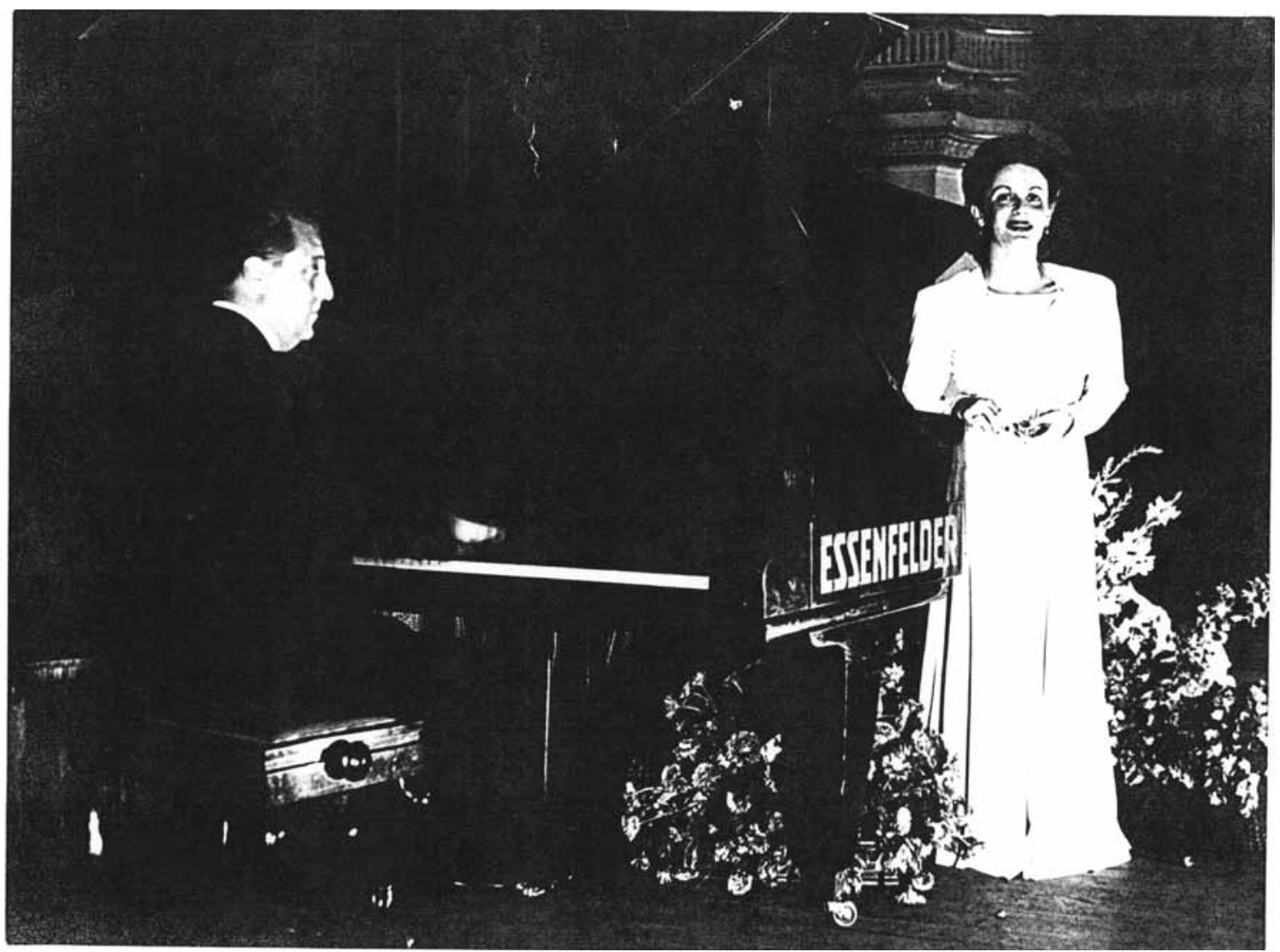

Ex.3 - Maria Sylvia e Francisco Mignone em recital na Escola Nacional de Música em 15 de agosto de 1944

(Foto cedida pela Academia Brasileira de Música). 
continuar esta luta em prol da valorização da produção artística nacional.

\section{Referências}

BANDEIRA, Manuel. A cinza das horas. Rio de Janeiro: Typographia do Jornal do Comércio, 1917.

BIBLIOTECA NACIONAL. Helza Camêu, uma compositora romântica. Jornal do Commércio, 1969 [citado em 1998]. Acervo da divisão de música da Biblioteca Nacional [on-line]. Disponível em: http://www.bn.br/musica/acervo.htm. Acesso em 29/jun/2006.

BORÉM, Fausto; CAVAZZOTI, André. Entrevista com Luciana Monteiro de Castro, Mônica Pedrosa e Margarida Borghoff sobre o projeto "Resgate da Canção Brasileira". In: Per Musi, Belo Horizonte, n. 15, 2007, p.78-86.

CORREA, Julieta. Entrevista concedida no Rio de Janeiro em 03/06/2006.

DUTRA, Luciana Monteiro de Castro Silva. Crepúsculo de Outono Op. 25 n. 2 para canto e piano de Helza Camêu:aspectos analíticos, interpretativos e biografia da compositora. (Dissertação de Mestrado) Escola de Música da Universidade Federal de Minas Gerais. Belo Horizonte: Universidade Federal de Minas Gerais, 2001.

MARIANNO, Olegário. O Enamorado da vida. Rio de Janeiro: Editora Guanabara, 1937.

. Quando vem baixando o crepúsculo. Rio de Janeiro: José Olympio Editora, 1944.

Toda uma vida de poesia. Rio de Janeiro: José Olympio Editora, 1958.

MÚSICA E MÚSICOS DO BRASIL: Maria Sylvia Pinto. Programa de rádio exibido pela Rádio MEC em 28 de março de 1988.

NEVES, José Maria. Prefácio. In: PINTO, Maria Sylvia. A canção brasileira - da modinha à canção de câmara. Rio de Janeiro: Companhia Brasileira de Artes Gráficas. 1985. p.9-16.

O GLOBO. Obituário. Rio de Janeiro, 01/09/1999, Caderno Rio, p.22.

PINTO, Maria Sylvia. A canção brasileira - da modinha à canção de câmara. Rio de Janeiro: Companhia Brasileira de Artes Gráficas. 1985.

TACUCHIAN, Ricardo. Depoimento concedido por e-mail em Maio de 2007.

VENTURA, Ricardo. O Instituto Villa-Lobos e a música popular. Rio de Janeiro, outubro de 2005. Disponível em: http:// brazilianmusic.com/articles/ventura-ivl.html. Acesso em 03/jun/2007.

\section{Notas}

1 Informação concedida por D. Julieta Correa em entrevista concedida no Rio de Janeiro em 3 de junho de 2006.

2 Canções brasileiras cantadas em primeiras audições por Maria Sylvia: de Villa-Lobos, as Serestas n. 13 (Serenata) e n. 14 (Vôo); de Helza Camêu, Serás, Serei, Poema da água, Canção, Noturno, Vela Branca, 0 livro de Maria Sylvia, 4 canções de Helena Kolody, entre outras; de Francisco Mignone, Pregão, Madrigal, 0 doce nome de você, As treis pinta, Cantiga do ai, Rudá Rudá; de Ernani Braga, Manhã; de Babi de Oliveira, Contradições, Maria Macambira, Vamo Saravá, entre outras; de Brasilio Itiberê, Guriatan de Coqueiro e Pescador da barquinha; entre outras de compositores como J. Octaviano, João de Souza Lima, Vieira Brandão, Osvaldo de Souza, Alceu Bocchino, José Siqueira, Arnaldo Rebello e Heloisa Magalhães.

3 Canções estrangeiras cantadas em primeiras audições por Maria Sylvia: Si tu aimes e Ami d'enfance, de Louis Beydts; Le marmitier e Le Berger, de Maurice Jaubert; Broulliard e Porquerolles, de Maurice Yvain; Piececitos, Elegia, El jugar, Al piente de La golondrina, Apegado a mi, La rosa y El sauce, Desde que te conoci, Se equivocó La Paloma, El vaso, El prisionero, Meciendo, A volar, Cita, Las nubes, Jardin Antiguo, Deseo, Alegria de La soledad, Por los campos verdes, Pueblito, mi pueblo, de Carlos Guartavino; entre outras dos compositores argentinos José Maria Castro, Emilio Dublanc, Pascual Quarantino, Angel Lasala, Manuel Gomez Carrillo e Isabel Aretz.

4 Não foram encontradas referências sobre as quatro peças avulsas apresentadas no lugar da ária de Ravel.

5 Citações de Helza Camêu extraídas do Prefácio escrito por José Maria Neves para o livro A Canção Brasileira - da Modinha à Canção de Câmara (PINTO, 1985, p.10).

Marcus Vinícius Medeiros Pereira é Mestre em Música - Performance/Piano pela Universidade Federal de Minas Gerais, tendo sido orientado pela Profa. Dra. Margarida Borghoff. Graduou-se no curso de Bacharelado em Piano nesta mesma instituição na classe do Prof. Dr. Miguel Rosselini, em 2005. É integrante do Grupo de Pesquisa Resgate da Canção Brasileira registrado no $\mathrm{CNPq}$, onde, além das atividades de pesquisa, atua como divulgador do gênero por meio de recitais em Belo Horizonte e cidades do interior de Minas Gerais. Durante o ano de 2008, foi professor de Piano e Música de Câmera do curso de Licenciatura em Música da Universidade Federal de Ouro Preto. Atualmente é professor do Curso de Licenciatura em Música da Universidade Federal de Mato Grosso do Sul. Nesta mesma instituição, cursa o doutorado em Educação, sendo orientado pela Profa. Dra. Fabiany de Cássia Tavares Silva. 